\title{
The Effects of Petroleum Hydrocarbons on Algae Can Be Reversed in the Presence of a Primary Consumer
}

\author{
Changyou Wang ${ }^{1,2} \cdot$ Yong Zhang $^{3} \cdot$ Hongli $\mathrm{Li}^{1,2} \cdot$ Wenhui Xing ${ }^{1} \cdot$ Hua $\mathrm{Yu}^{1}$
}

Received: 9 December 2014/ Accepted: 30 June 2015/Published online: 10 July 2015

(C) Springer Science+Business Media New York 2015

\begin{abstract}
The ecotoxicological effects of a mixture of petroleum hydrocarbons were tested on densities of two algae, Platymonas helgolandica var. tsingtaoensis and Isochrysis galbana, and of a rotifer, Brachionus plicatilis, by single-species and customized community experiments. Test concentrations ranged from 0 to $100 \mathrm{mg} \mathrm{L}^{-1}$, while five to seven treatments were assessed in triplicate within 1 month. A significant decrease in densities during singlespecies toxicity tests were found when concentrations of petroleum hydrocarbons were above $1.0 \mathrm{mg} \mathrm{L}^{-1}$. However, equilibrium densities of algae in the customized community showed a different pattern, which increased with concentration and reached a peak at $20.0 \mathrm{mg} \mathrm{L}^{-1}$. The community-based no observed effect concentration (NOEC; $1.0 \mathrm{mg} \mathrm{L}^{-1}$ ) was different from the NOEC derived by single-species toxic tests $\left(0.25 \mathrm{mg} \mathrm{L}^{-1}\right)$. This demonstrates that ecotoxicological effects on plankton as part of a community is significantly different from singlespecies toxicity tests owing to ecological interactions.
\end{abstract}

Keywords Ecotoxicological effect - Ecological interaction · Indirect effect $\cdot$ NOEC $\cdot$ Petroleum hydrocarbons

Changyou Wang

chy.w@hotmail.com

1 School of Marine Sciences, Nanjing University of Information Science and Technology, Nanjing 210044, China

2 Jiangsu Engineering Technology Research Center of Marine Environment Detection, Nanjing 210044, China

3 Key Laboratory of Coastal Zone Environmental Processes, Yantai Institute of Coastal Zone Research, Chinese Academy of Sciences, Yantai 264003, China
Petroleum hydrocarbons are multi-component homogeneous mixtures with complex molecular structure and composed of alkanes, alkenes, aromatic hydrocarbons and heterocyclic aromatic ones (Zakaria et al. 2000), which all have toxic effects on the marine plankton (Huang et al. 2011; Lu and He 2000). Petroleum hydrocarbons are the major constituents of oil pollutants. It is estimated that more than 5.74 million tonnes of crude oil are released into the ocean water from 1970 to 2013 (The International Tanker Owners Pollution Federation (ITOPF) 2013), of which more than $90 \%$ is directly related to human activities. Large-scale marine oil spill accidents have received great attention due to their catastrophic damage to the environment. For example, the devastating British Petroleum oil spill due to the explosion of the Trans-ocean Deepwater Horizon rig in 2010 and the Conocophillips oil spill in Bohai Sea, China, in 2011, which all caused and are still causing loss of species diversity and habitat, destruction of ecological balance of halobios and death of endemic species (Ndimele et al. 2010; Nikolopoulou and Kalogerakis 2009). Although the number of oil spills and the volume of oil spilt from tankers show a marked reduction through the decades (The International Tanker Owners Pollution Federation (ITOPF) 2013), the non-point source discharges demonstrate a significant increase (Guan et al. 2015). With the increasing offshore exploration and development of oil and maritime transport, minor oil spills and oil contamination have become threats to environmental health. According to the report of China's marine environmental quality communique (China State Oceanic Administration 2014), petroleum hydrocarbons have become the main pollutants next to nutrients (i.e. nitrate, phosphate) in the China Sea.

There are many papers reporting the toxic effects of petroleum hydrocarbons on marine species and discussing 
the factors driving the effect of oil spills on marine species assemblages (Echeveste et al. 2010; González et al. 2009; Huang et al. 2011; Sargian et al. 2005; Shi et al. 2001; Tintos et al. 2007). However, these papers are mainly restricted to single-species toxicity tests and the impact of environmental abiotic factors on toxic effect. In fact, the indirect effects of ecological relationships on the toxic effects between populations in communities are significant and should not be ignored (Fleeger et al. 2003; Bernot and Turner 2001). Indirect effect in ecological communities induced by contaminants have been detected widely in natural and manipulative communities and recognized as being able to change species abundances, alter community composition, and weaken or enhance direct contaminant effects (Bernot and Turner 2001; Fleeger et al. 2003; O'Connor et al. 2013; Reinhardt et al. 2013; Wootton 2002)

In order to study such indirect effects of ecological relationships, a simple controlled community needs be designed. Platymonas helgolandica var. tsingtaoensis is a unicellular alga of the Chlorophyta, and Isochrysis galbana a unicellular alga of the Chrysophyta. They are found widely in coastal waters in the world, are easy to culture and often used as food in aquaculture (Ma 2013; Sun et al. 2005). Rotifers are also widely found in coastal waters in the world, and form a fundamental constituent of the zooplankton community and play thus a significant role in energy flow in marine ecosystems. The rotifer Brachionus plicatilis reproduces rapidly, is adaptable, has a short life cycle, and is often used as tested organism in studies of ecotoxicology and environmental monitoring worldwide (Fang et al. 2013). Therefore, a community consisting of $P$. helgolandica var. tsingtaoensis, I. galbana and B. plicatilis, is customized to measure the toxic effects of petroleum hydrocarbons and to discuss the impact of ecological relationships on toxic effects of petroleum hydrocarbons. Finally, a no observed effect concentration (NOEC) of petroleum hydrocarbon for the customized plankton community is obtained with an endpoint manifesting interspecies competition-grazing relationships and related to single species test results.

\section{Materials and Methods}

The petroleum hydrocarbon mixture used in this study was the water-accommodated fraction of crude oil obtained from Bohai offshore oil field, China. The sample of this crude oil contains $87.6 \%$ of carbon, $11.6 \%$ of hydrogen, $0.4 \%$ of nitrogen and $0.2 \%$ of sulfur, classified as low sulfur naphthene base oil. Ultraviolet Spectrophotometry [UV-2102PCS, Unico (Shanghai) Instrument Co., Ltd] was used to determine petroleum hydrocarbons concentrations at $225 \mathrm{~nm}$ according to the specification for marine monitoring (General Administration of Quality Supervision, Inspection and Quarantine of the People's Republic of China (AQSIQ) 2008).

In algae single-species toxicity tests, the test concentration of the petroleum hydrocarbons was $0,0.25,1,10$, 20, 40 and $100 \mathrm{mg} \mathrm{L}^{-1}$, which were determined with a preliminary experiment, and the corresponding measured concentrations in the end of test were $0,0.21,0.92,9.5$, 19.1, 39.1 and $98.2 \mathrm{mg} \mathrm{L}^{-1}$, respectively. The analytical limits of detection were $0.002 \mathrm{mg} \mathrm{L}^{-1}$ and the average relative standard deviation $<2 \%$. The algae ( $P$. helgolandica var. tsingtaoensis and I. galbana.) were cultivated in $300 \mathrm{~mL}$ conical flask of $150 \mathrm{~mL}$ culture medium. The culture medium was prepared from Nitrate, phosphate, vitamins and trace elements in natural, filtered $(<20 \mu \mathrm{m})$ autoclaved seawater according to $\mathrm{f} / 2$ medium (Lananan et al. 2013). The seawater was sourced from the China Sea near Qidong county, where salinity is approximately 30 psu. The measured concentration of nutrients by spectrophotometric methods was $224 \mu \mathrm{g} \mathrm{L}{ }^{-1}$ for $\mathrm{NO}_{3}-\mathrm{N}$, $6.2 \mu \mathrm{g} \mathrm{L}^{-1}$ for $\mathrm{PO}_{4}-\mathrm{P}$ and $281 \mu \mathrm{g} \mathrm{L}^{-1}$ for $\mathrm{SiO}_{3}-\mathrm{Si}$ in the collected seawater (Wei et al. 2011; Wang and Morrison 2014). The measured concentration of heavy metals by atomic absorption spectrometry was $0.64 \mu \mathrm{g} \mathrm{L}^{-1}$ for $\mathrm{Cu}$, $0.62 \mu \mathrm{g} \mathrm{L}^{-1}$ for $\mathrm{Pb}, 7.2 \mu \mathrm{g} \mathrm{L}^{-1}$ for $\mathrm{Zn}, 0.11 \mu \mathrm{g} \mathrm{L}^{-1}$ for $\mathrm{Cd}, 0.73 \mu \mathrm{g} \mathrm{L}^{-1}$ for total $\mathrm{Cr}$ and $0.04 \mu \mathrm{g} \mathrm{L}{ }^{-1}$ for total $\mathrm{Hg}$ (Wang et al. 2009; Wang et al. 2015). The measured concentration of persistent organic pollutants (POPs) was $2.88 \mathrm{ng} \mathrm{L}^{-1}$ for total organic chlorine pesticide and $9.51 \mathrm{ng} \mathrm{L}^{-1}$ for polychlorinated biphenyls (Huo 2011). The conical flasks were put in an incubator with a constant temperature of $23^{\circ} \mathrm{C}$, a photoperiod of $12 \mathrm{~h}$ light: $12 \mathrm{~h}$ dark and a photon irradiance of ca. $60 \mu \mathrm{mol} \mathrm{m} \mathrm{m}^{-2} \mathrm{~s}^{-1}$. The algal initial incubation density was $0.20 \times 10^{6}$ cells $\mathrm{mL}^{-1}$ for $P$. helgolandica var. tsingtaoensis and $0.47 \times 10^{6}$ cells $\mathrm{mL}^{-1}$ for I. galbana. The algal single-species toxicity tests lasted until the densities started to decline, and the longest time was 8 days. During the experiment period, 5-mL water samples were taken every day from the culture flask, fixed by the addition of Lugol's solution. Algae species composition and cell number were determined by light microscopy (XLE-2, 3DFAMILY Technology Co., Ltd, Nanjing, China). Three replicates were used per treatment. The same culture conditions, research item and concentration gradient of the petroleum hydrocarbons were used in the algae bi-species toxicity tests.

In rotifer single-species toxicity tests, the test concentration of the petroleum hydrocarbons, also determined with a preliminary experiment, was $0,0.25,1,5,10$ and $20 \mathrm{mg} \mathrm{L}^{-1}$, and the corresponding measured concentrations in the end of test was $0,0.21,0.92,4.6,9.5$ and $19.1 \mathrm{mg} \mathrm{L}^{-1}$, respectively. The culture of rotifer $B$. plicatilis were conducted in 
$300 \mathrm{~mL}$ conical flask of $150 \mathrm{~mL}$ culture medium. The initial density was ten individuals $\mathrm{mL}^{-1}$. The culture flasks were put in an incubator with the same temperature and photoperiod as the algae single-species toxicity tests, and fed every $24 \mathrm{~h}$ with the algae Chlorella $\mathrm{sp}$. at a density of $1 \times 10^{6}$ cells $\mathrm{mL}^{-1}$ (Zhou 2005). Each culture flasks was observed in every day and the survival number was determined. The test ended when all the rotifer monitored in this test died. Three replicates per treatment were used.

In the customized plankton community toxicity test, the test concentration of the petroleum hydrocarbons was 0 , $0.25,1,10,20$ and $40 \mathrm{mg} \mathrm{L}^{-1}$, and the corresponding measured concentrations in the end of test was $0,0.21$, $0.92,9.5,19.1$ and $39.1 \mathrm{mg} \mathrm{L}^{-1}$, respectively. The initial density was $0.20 \times 10^{6}$ cells $\mathrm{mL}^{-1}$ for $P$. helgolandica var. tsingtaoensis, $0.47 \times 10^{6}$ cells $\mathrm{mL}^{-1}$ for I. galbana and five individuals $\mathrm{mL}^{-1}$ for $B$. plicatilis. The initial rotifers were selected from the motile individuals cultured in the same conditions. Three species of plankton were cultivated in $1 \mathrm{~L}$ conical flask of $0.5 \mathrm{~L}$ culture medium. The culture flasks were put in an incubator with the same temperature and photoperiod as the single-species toxicity tests. The variation in species and density of planktons were determined every 2 days in the first 10 days and every 5 days afterwards, using the same counting methodology described above. The customized plankton community toxicity test lasted 25 days. Three replicates were used per treatment.

The ecotoxicological effect of petroleum hydrocarbons in algae single-species toxicity tests was estimated with the endpoint of carrying capacity, which was a parameter of logistic growth model denoting algae maximum population density and fitted for an endpoint of the toxic effect (Wang et al. 2011). The ecotoxicological effect in rotifer singlespecies toxicity test was estimated with the endpoint of survival rate, which was sensitive to petroleum and fitted for an endpoint of the toxic effect on zooplankton (Gomiero et al. 2012). The ecotoxicological effect in the customized plankton community toxicity test was estimated with the endpoint of equilibrium densities of three species. For a community consisting of three species, equilibrium densities were the unique positive asymptotic population densities in a balance position (Wang et al. 1994; Chen et al. 2009). In this study, if the densities of three species were not changed significantly in 5 days, the community was supposed to get the balance between them and the averages of densities for each species in 5 days were calculated to be equilibrium densities.

A NOEC of petroleum hydrocarbons, the maximum concentration which does not affect the density amount of the test species, is determined for the customized plankton community and each species. In this study, the carrying capacity of alga population or survival rate of rotifer population in treatments of a single-species toxicity test was compared with the corresponding reference data (the control), and yielded a population-NOEC for each plankton population. The community-NOEC for the customized plankton community was the highest test concentration to which exposure of the community will not affect significantly any of the populations (Laender et al. 2008), and determined by comparing equilibrium densities of three species in all treatments of the customized community toxicity test with that in the control. A one-sided Dunnett test $(\alpha=5 \%)$, developed for comparing several independent treatments with a control (Dunnett 1955, 1964), was used to calculate NOEC for the test plankton.

\section{Results and Discussion}

As can be seen from Figs. 1 and 2, without exposure to petroleum hydrocarbon, the carrying capacity calculated with logistic growth model, was up to $121.56 \times 10^{6}$ cells $\mathrm{mL}^{-1}$ in alga single-species test and $107.86 \times 10^{6}$ cells mL $^{-1}$ in algae bi-species test for $P$. helgolandica var. tsingtaoensis, whereas $1019.7 \times 10^{6}$ and $536.35 \times 10^{6}$ cells $\mathrm{mL}^{-1}$ where the carrying capacity for I. galbana, respectively. These data demonstrated that interspecies competition between two algal species caused a reduction of $12 \%$ in $P$. helgolandica var. tsingtaoensis density and of $48 \%$ in I. galbana density under control conditions. The densities for each species in the customized plankton community test tended to stability after 10 days and did not change significantly over another 5 days (Fig. 3). It is more impressed that the equilibrium density of $P$. helgolandica var. tsingtaoensis and I. galbana in the customized community, in absence of petroleum hydrocarbons,

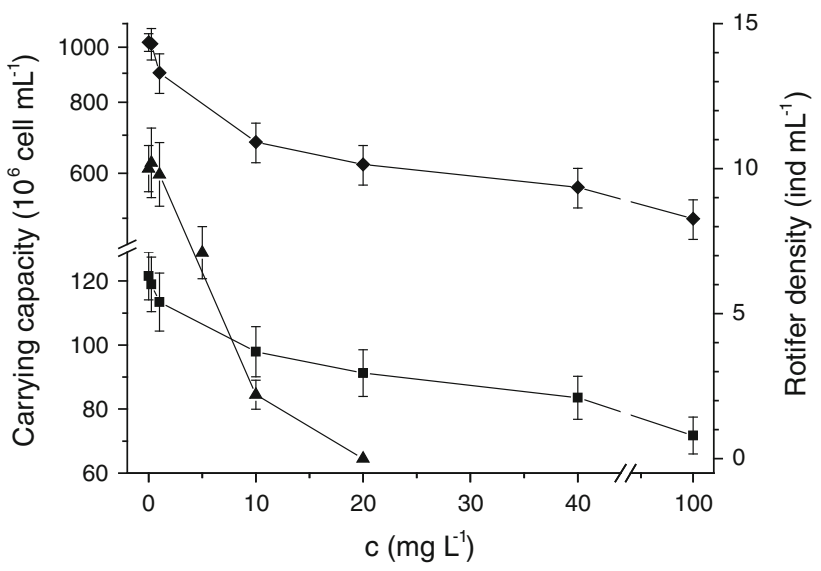

Fig. 1 Changes of carrying capacity and rotifer density with petroleum hydrocarbons concentration in single-species toxicity tests (the dots displaying were mean values and the error bars stood for standard deviations; filled square: P. helgolandica var. tsingtaoensis; filled diamond: I. galbana; filled triangle: B. plicatilis.) 


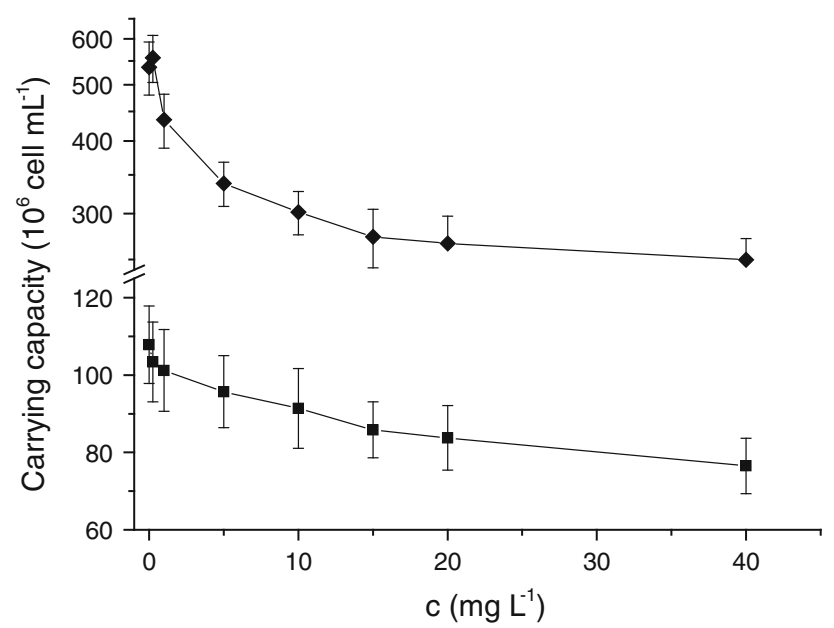

Fig. 2 Changes of carrying capacity with petroleum hydrocarbons concentration in algae bi-species toxicity tests (the dots displaying were mean values and the error bars stood for standard deviations; filled square: P. helgolandica var. tsingtaoensis; filled diamond: I. galbana.)

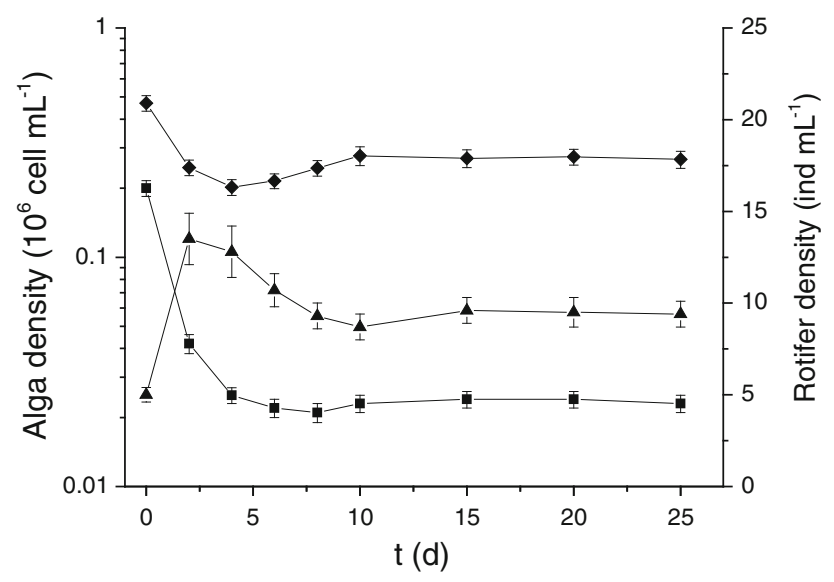

Fig. 3 Plankton densities over time in the unexposed customized plankton community toxicity test (the dots displaying were mean values and the error bars stood for standard deviations; filled square: P. helgolandica var. tsingtaoensis; filled diamond: I. galbana; filled triangle: $B$. plicatilis.)

was only $0.024 \times 10^{6}$ and $0.27 \times 10^{6}$ cells $\mathrm{mL}^{-1}$, respectively. That is, grazing of zooplankton resulted in a greater decrement of more than 3000 times in the algea's density if compared with carrying capacity in the algae single-species test.

When exposed to a petroleum hydrocarbons concentration higher than $1.0 \mathrm{mg} \mathrm{L}^{-1}$, the response of carrying capacity showed a decreasing trend in algae single-species toxicity tests (Fig. 1), indicating the enhanced toxic effect on the phytoplankton population. It is the same pattern as the carrying capacity in algae bi-species toxicity tests (Fig. 2). The representative measurement demonstrated that petroleum hydrocarbon-related exposures caused a

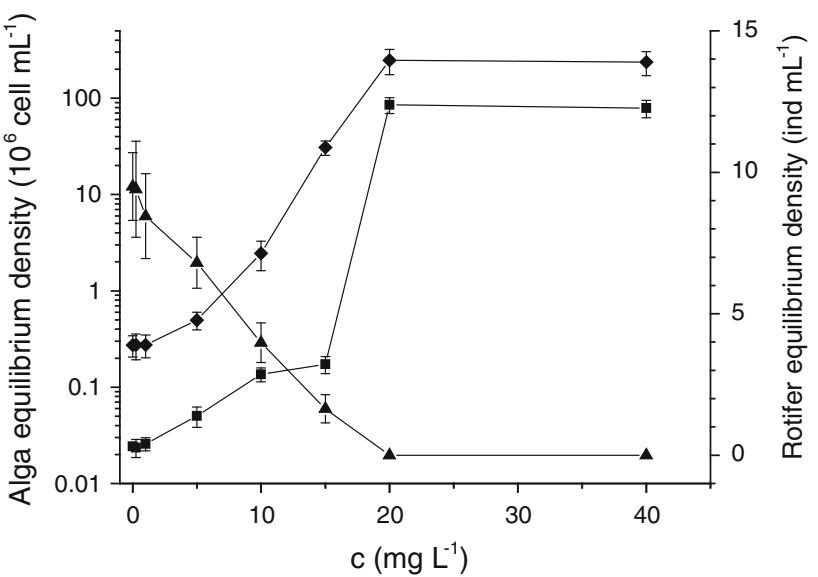

Fig. 4 Changes of plankton equilibrium density with petroleum hydrocarbons concentration in the customized plankton community toxicity test (the dots displaying were mean values and the error bars stood for standard deviations; filled square: P. helgolandica var. tsingtaoensis; filled diamond: I. galbana; filled triangle: B. plicatilis.)

$26 \%$ reduction in $P$. helgolandica var. tsingtaoensis density at a concentration of $20.0 \mathrm{mg} \mathrm{L}^{-1}$ in alga single-species toxicity test, whereas petroleum hydrocarbons-related exposure plus interspecies competition caused a $32 \%$ reduction in algae bi-species toxicity tests. However, a clear decrement from $76 \%$ to $39 \%$ in I. galbana density was observed for algae single- and bi-species toxicity tests (Fig. 2). This implied the taxonomic difference in impact of interspecies competition on toxic effect of petroleum hydrocarbons and possibility of subsequent variation in the community structure.

As shown in Fig. 4, the B. plicatilis density in the customized plankton community toxicity test decreased from concentration higher than $1.0 \mathrm{mg} \mathrm{L}^{-1}$ and tended to zero at petroleum hydrocarbon concentrations of $20.0 \mathrm{mg} \mathrm{L}^{-1}$. This pattern is similar to that in the rotifer single-species toxicity test (Fig. 1). However, the equilibrium densities of $P$. helgolandica var. tsingtaoensis and I. galbana in the customized community showed a different pattern, which increased with the petroleum hydrocarbon concentrations and reached a peak at $20.0 \mathrm{mg} \mathrm{L}^{-1}$ (Fig. 4). This phenomenon is related to trophic cascades, a well-studied type of indirect effect (Fleeger et al. 2003; Wootton 2002). It demonstrated that the decrease in plankton densities with increasing toxicant concentrations in single-species tests does not necessarily imply a decrease effect on their densities within a community, since their densities also depend on ecological interactions (Laender et al. 2008). The combination of a decline of intrinsic growth rate with a reduced grazing pressure of zooplankton - here the rotifer - is proposed as an explanation for the increase of phytoplankton densities. This kind of combination of direct and indirect effects would not have been discovered using 
single- or even bi-species toxicity test (Oskarsson et al. 2014).

The trophic cascades have already been documented in many studies and often arose jointly with interspecies competition, another representative of indirect effect (Fleeger et al. 2003; Mayer-Pinto et al. 2015; Oskarsson et al. 2014; Reinhardt et al. 2013; Wootton 2002). And it was found to be difficult to distinguish the latter from the former in such a case (Fleeger et al. 2003; Wootton 2002). In this study, when concentration of petroleum hydrocarbons increased from 20 to $40.0 \mathrm{mg} \mathrm{L}^{-1}$, alga density decreased from $85.45 \times 10^{6}$ to $78.82 \times 10^{6}$ cells $\mathrm{mL}^{-1}$ for $P$. helgolandica var. tsingtaoensis and $247.7 \times 10^{6}$ to $237.4 \times 10^{6}$ cells $\mathrm{mL}^{-1}$ for I. galbana, respectively, which were almost the same with those in algae bi-species test. It was obvious that the $B$. plicatilis. died out at a petroleum hydrocarbons concentration of $40.0 \mathrm{mg} \mathrm{L}^{-1}$ and the grazing effect of zooplankton consequently vanished. This indicated a termination of trophic cascades and only competition between the two algal species was responsible for the indirect effect in the community. The algae densities at these concentrations were more than 800 times larger than that at a concentration below $1.0 \mathrm{mg} \mathrm{L}^{-1}$ in the customized plankton community toxicity test, but showed a decrease of more than $35 \%$ if compared with the carrying capacity at a concentration below $1.0 \mathrm{mg} \mathrm{L}^{-1}$ in the algae single-species test. By comparison, competition was distinguished from trophic cascade and manifested to be weaker than the latter in this study. Furthermore, the dramatic changes of algae densities in the customized community toxicity test also manifested that grazing effect of zooplankton on density of phytoplankton was stronger than toxic effects of petroleum hydrocarbons at the present concentrations. Therefore, the indirect effect mediated through interspecies interaction had a great impact on ecotoxicological effect of petroleum hydrocarbons on phytoplankton. The similar phenomena were observed on sessile organisms, nekton and marine benthos in the intertidal and coastal communities (Fleeger et al. 2003; Mayer-Pinto et al. 2015; O'Connor et al. 2013; Oskarsson et al. 2014; Wootton 2002), which demonstrated that indirect effects were widely existent and fundamental to ecosystems (Wootton 2002).

The comparison of the treatments in single-species toxicity test with the corresponding control, resulted in a NOEC of $1.0 \mathrm{mg} \mathrm{L}^{-1}$ for $P$. helgolandica var. tsingtaoensis, $0.25 \mathrm{mg} \mathrm{L}^{-1}$ for I. galbana and $1.0 \mathrm{mg} \mathrm{L}^{-1}$ for B. plicatilis. If NOEC for a community relied on the extrapolation of single-species toxic effect to communitylevel effect and was defined as the lowest populationNOEC (Laender et al. 2008), the derived NOEC for the customized community should be $0.25 \mathrm{mg} \mathrm{L}^{-1}$. However, by comparing the treatments in the customized community toxicity test with the control, the determined communityNOEC was $1.0 \mathrm{mg} \mathrm{L}^{-1}$. This NOEC was a result of indirect effects mediated through interspecies interactions, which could buffer for severe direct effects (Fleeger et al. 2003; Wootton 2002). The decreased density of I. galbana after exposure to a concentration of $1.0 \mathrm{mg} \mathrm{L}^{-1}$ likely led to a more grazing on $P$. helgolandica var. tsingtaoensis by B. plicatilis. Less rotifer grazing may have counteracted the negative effect of the exposure on I. galbana at higher concentrations. This resulted in an increased NOEC for $I$. galbana. The positive change of NOEC would not have been observed using simpler single-species study designs. In a sense, ecotoxicological measures on community level should better predict the effects on ecosystems than the measures on individual and population level (Forbes and Calow 1999; Oskarsson et al. 2014), therefore, the NOEC determined with the customized plankton community toxicity test might be more reliable than those with singlespecies toxicity tests in the present study.

Acknowledgments This study was supported by the Natural Science Foundation of Jiangsu Province, China (Project No. BK20141478), the Natural Science Foundation of the Jiangsu Higher Education Institutions of China (Project No. 14KJB170016), the National Natural Science Foundation of China (Project No. 41371314), and the Priority Academic Program Development of Jiangsu Higher Education Institutions (PAPD).

\section{References}

Bernot RJ, Turner AM (2001) Predator identity and trait-mediated indirect effects in a littoral food web. Oecologia 129(1):139-146

Chen LX, Meng XZ, Jiao JJ (2009) Biodynamics. Science Press, Beijing

China State Oceanic Administration (2014) The report of China's marine environmental quality communique in 2010. http://www. coi.gov.cn/gongbao/huanjing/. Accessed 26 June 2014

Dunnett CW (1955) A multiple comparison procedure for comparing several treatments with a control. J Am Stat Assoc. 50(12):10961121

Dunnett CW (1964) New tables for multiple comparison with a control. Biometrics 20:482-491

Echeveste P, Agust AS, Dachsb J (2010) Cell size dependent toxicity thresholds of polycyclic aromatic hydrocarbons to natural and cultured phytoplankton populations. Environ Pollut 158(1):299-307

Fang K, Tang XX, Zhang J, Wang Y (2013) Effects of different species and densities of marine bait microalgae on feeding of rotifer Brachionus plicatilis neonates. Mar Environ Sci 32(4):497-501

Fleeger JW, Carman KR, Nisbet RM (2003) Indirect effects of contaminants in aquatic ecosystems. Sci Total Environ 317: 207-233

Forbes V, Calow P (1999) Is the per capita rate of increase a good measure of population-level effects in ecotoxicology? Environ Toxicol Chem 18:1544-1556

General Administration of Quality Supervision, Inspection and Quarantine of the People's Republic of China (AQSIQ) (2008) The specification for marine monitoring-part 4: seawater analysis (GB17378.4-2007). Standards Press of China, Beijing 
Gomiero A, Sforzini S, Dagnino A, Nasci C, Viarengo A (2012) The use of multiple endpoints to assess cellular responses to environmental contaminants in the interstitial marine ciliate Euplotes crassus. Aquat Toxicol 114-115:206-216

González J, Figueiras FG, Aranguren-Gassis M, Crespo BG, Fernández E, Morán XAG, Nieto-Cid M (2009) Effect of a simulated oil spill on natural assemblages of marine phytoplankton enclosed in microcosms. Estuar Coast Shelf Sci 83(3):265-276

Guan XH, Guo LC, Bao LJ, Zeng YP (2015) Oil products in wet deposition and their impacts on regional water environment: a case study of n-alkanes. Environ Chem 34(1):9-17

Huang YJ, Chen QZ, Zeng JN, Jiang ZB (2011) The impact of oil pollution on marine phytoplankton community growth change. Acta Ecol Sin 31(2):513-521

Huo Y (2011) Study of major environmental problems in offshore China. Third institute of oceanography, Hangzhou

Laender FD, Schamphelaere KACD, Vanrolleghem PA, Janssen CR (2008) Comparison of different toxic effect sub-models in ecosystem modelling used for ecological effect assessments and water quality standard setting. Ecotoxicol Environ Saf 69:13-23

Lananan F, Jusoh A, Ali N, Lam SS, Endut A (2013) Effect of Conway Medium and $\mathrm{f} / 2$ Medium on the growth of six genera of South China Sea marine microalgae. Bioresour Technol 141:75-82

Lu HY, He ZH (2000) Toxicity of crude oil and refined oils from Daqing to Moina mongolica Dady. J Dalian Fish Univ 15(3):169-174

Ma S (2013) Toxicity of crude oil and four kinds of dispersants to P.helgolandica and N.closterium. Ocean University of China, Qingdao

Mayer-Pinto M, Underwood AJ, Marzinelli EM (2015) The matrix influences direct and indirect effects of an anthropogenic disturbance on marine organisms. Environ Res 136:15-20

Ndimele PE, Jenyo-Oni A, Jibuike CC (2010) Comparative toxicity of crude oil, dispersant and crude oil-plus-dispersant to Tilapia guineensis. Res J Environ Toxicol 4(1):13-22

Nikolopoulou M, Kalogerakis N (2009) Biostimulation strategies for fresh and chronically polluted marine environments with petroleum hydrocarbons. J Chem Technol Biotechnol 84(6): 802-807

O'Connor NE, Emmerson MC, Crowe TP, Donohue I (2013) Distinguishing between direct and indirect effects of predators in complex ecosystems. J Anim Ecol 82(2):438-448

Oskarsson H, Eriksson Wiklund A-K, Thorsén G, Danielsson G, Kumblad L (2014) Community interactions modify the effects of pharmaceutical exposure: a microcosm study on responses to propranolol in baltic sea coastal organisms. PLoS One 9(4):e93774

Reinhardt T, Steinfartz S, Paetzold A, Weitere M (2013) Linking the evolution of habitat choice to ecosystem functioning: direct and indirect effects of pond-reproducing fire salamanders on aquaticterrestrial subsidies. Oecologia 173(1):281-291

Sargian P, Mostajir B, Chatila K, Ferreyra GA, Pelletier É, Demers S (2005) Non-synergistic effect $s$ of water-soluble crude oil and enhanced ultraviolet-B radiation on a natural plankton assemblage. Mar Ecol Prog Ser 294:63-77

Shi XY, Wang XL, Han XR, Jiang Y, Zhu MY, Chen S, Koshikawa H (2001) Relationship between petroleum hydrocarbon and plankton in a mesocosm experiment. Acta Oceanol Sin 20(2):231-240

Sun YY, Sun LQ, Wang CH (2005) Study on the Growth of Isochrysis galbana. Mar Sci Bull 24(3):92-96

The International Tanker Owners Pollution Federation (ITOPF) (2013) Oil tanker spill statistics 2013. http://www.itopf.com/ knowledge-resources/data-statistics/statistics. Accessed 26 June 2014

Tintos A, Gesto M, Míguez ZJ, Soengas JL (2007) Naphthalene treatment alters liver intermediary metabolism and levels of steroid hormones in plasma of rainbow trout (Oncorhynchus mykiss). Ecotoxicol Environ Saf 66(2):139-147

Wang C, Morrison John (2014) Phosphorus speciation and changes with depth in the sediment of Lake Illawarra, New South Wales, Australia. Environ Earth Sci 71(8):3529-3541

Wang SQ, Ha LM, Cao YZ, Yu YH (1994) The ecological stability of some models of three-population community. J Northwest Natl Univ (Nat Sci) 15(1):5-8

Wang C, Wang X, Wang B, Zhang C, Shi X, Zhu C (2009) Level and fate of heavy metals in the Changjiang estuary and its adjacent waters. Oceanology 49(1):64-72

Wang CY, Wang XL, Su RG, Liang SK, Yang SP (2011) No detected toxic concentrations in in situ algal growth inhibition tests-a convenient approach to aquatic ecotoxicology. Ecotoxicol Environ Saf 74:225-229

Wang C, Liang S, Li Y, Li K, Wang X (2015) The spatial distribution of dissolved and particulate heavy metals and their response to land-based inputs and tides in a semi-enclosed industrial embayment: Jiaozhou Bay. Environmental Science and Pollution Research, China. doi:10.1007/s11356-015-4259-3

Wei Q, Zang J, Wei X, Liu L (2011) Tht distribution of nutrients and the relationship of themwith the circulation condition in the western southern Huanghai Sea in autumn. Acta Oceanol Sin $33(1): 74-81$

Wootton JT (2002) Indirect effects in complex ecosystems: recent progress and future challenges. J Sea Res 48(2):157-172

Zakaria MP, Horinouchi A, Tsutsumi S, Takada H, Tanabe S, Ismail A (2000) Oil pollution in the straits of Malacca, Malaysia: application of molecular markers for source identification. Environ Sci Technol 34(7):1189-1196

Zhou WL (2005) The studies on ingestion, reproduction and population dynamics of Brachionus plicatilis. Ocean University of China, Qingdao 